\title{
Descriptive Analysis: Television Uses among Community in Rural Area, Sarawak
}

Ribka Alan, Md Salleh Hassan, Jusang Bolong, Mohd Nizam Osman, Philip Lepun, Shafinah Kamarudin

To Link this Article: http://dx.doi.org/10.6007/IJARBSS/v11-i11/11605

DOI:10.6007/IJARBSS/v11-i11/11605

Received: 09 September 2021, Revised: 11 October 2021, Accepted: 27 October 2021

Published Online: 19 November 2021

In-Text Citation: (Alan et al., 2021)

To Cite this Article: Alan, R., Hassan, M. S., Bolong, J., Osman, M. N., Lepun, P., \& Kamarudin, S. (2021). Descriptive Analysis: Television Uses among Community in Rural Area, Sarawak. International Journal of Academic Research in Business and Social Sciences, 11(11), 1258-1272.

Copyright: @ 2021 The Author(s)

Published by Human Resource Management Academic Research Society (www.hrmars.com)

This article is published under the Creative Commons Attribution (CC BY 4.0) license. Anyone may reproduce, distribute, translate and create derivative works of this article (for both commercial and non-commercial purposes), subject to full attribution to the original publication and authors. The full terms of this license may be seen at: http://creativecommons.org/licences/by/4.0/legalcode

Vol. 11, No. 11, 2021, Pg. 1258 - 1272

Full Terms \& Conditions of access and use can be found at http://hrmars.com/index.php/pages/detail/publication-ethics 


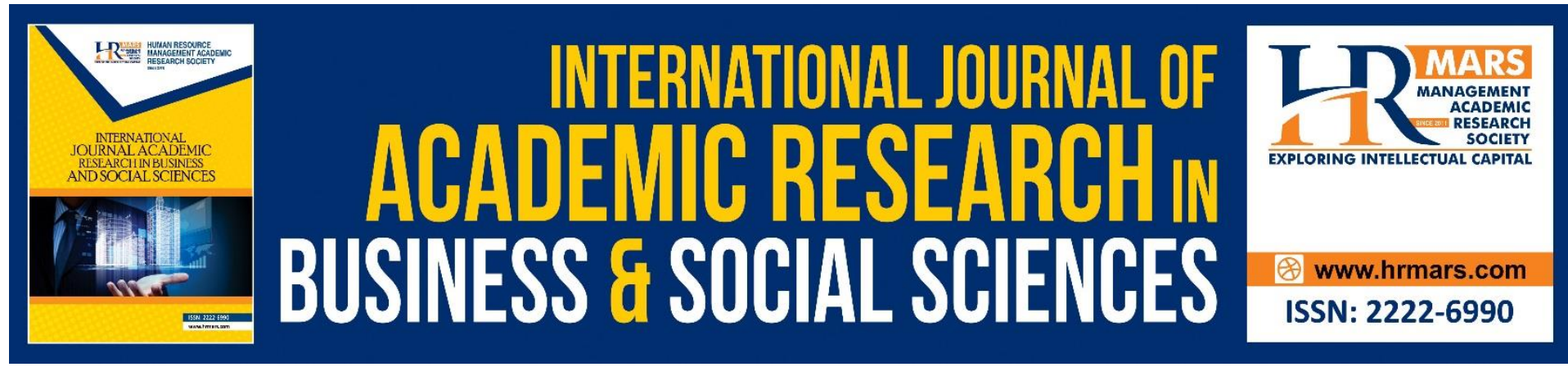

\title{
Descriptive Analysis: Television Uses among Community in Rural Area, Sarawak
}

\section{Ribka Alan ${ }^{1}$, Md Salleh Hassan², Jusang Bolong², Mohd Nizam} Osman $^{2}$, Philip Lepun ${ }^{3}$, Shafinah Kamarudin ${ }^{4}$

${ }^{1}$ Faculty of Humanities, Management and Science, Universiti Putra Malaysia Bintulu Sarawak Campus, Sarawak, Malaysia, ${ }^{2}$ Faculty of Modern Languages and Communication, Universiti Putra Malaysia, Serdang, Selangor, Malaysia, ${ }^{3}$ Faculty of Agriculture and Forestry Science, Universiti Putra Malaysia Bintulu Sarawak Campus, Sarawak, Malaysia, ${ }^{4}$ Faculty of Computer Science and Information Technology, Universiti Putra Malaysia, Serdang, Selangor, Malaysia Email Correspondence: ribka@upm.edu.my

\begin{abstract}
Television channel is used to convey messages of development agendas by the ruling government. Delivery of information through television channels especially in rural areas is still questionable because of the effectiveness level is influenced by their demographic features. Therefore, this study was conducted to identify the population demographics with the frequency use of television for information searching that ultimately affects the rural community quality of life. The respondents were determined based on statistical analysis. A total of 356 respondents were involved from Asap Koyan Resettlement in Belaga, Sarawak. The data collection was using questionnaires and interview as well. The results showed that the primary government information seeking via Media Prima 44.2\% and RTM 39.2\%, sports, and recreational information via ASTRO channel 43.9\% and other information through different channels $47.6 \%$. The findings also show that respondents have never and rarely watched television for a week. Based on the results of this study, television has less been chosen due to the low education level and cost of living constraints. In the future, television channels advice to broadcast more programmes specifically for the Sarawak rural community at the appropriate time to watch for up grading quality of life and their development benefits. Keywords: Ethnicity, Television, Farmer Community, Quality of Life, Descriptive Analysis
\end{abstract}

\section{Introduction}

Television is an important communication channel in shifting the thinking of a country's society to change in practicing their racial identity. The development policies and agendas targeted by the government need to be better understood by the people through mass media channels. Therefore, television channel services in Malaysia have started their operation on 28 December 1968. Radio Televisyen Malaysia (RTM) was the first broadcaster in Malaysia. RTM has started two television channels, namely TV1 and TV2 in 1969. RTM is known as a government-owned television station. Further, the very rapid changes underpinned by communication channel services caused the Malaysian government to open more television 
stations to private companies. The Malaysian government owns RTM as its main television station. Meanwhile, Media Prima and ASTRO are two prominent private companies that own television stations with hundreds of television channels such as TV3, TV8, NTV7, TV9, Astro Prima and Astro Warna (Hassan et al., 2011; Hashim \& Omar, 2011; Wawarah, 2017).

The government's efforts in conveying various information to farmers scattered across the country through television channels have become an option for extension agents. According to Irfan et al (2006), farmers prefer to choose television channels as the most effective mass media to convey agricultural information. This is followed by other communication channels such as radio and print media. For the need to obtain information, farmers prefer to choose television medium to find information such as weather, Information and Communication Technology (ICT), and agricultural markets (Hassan et al., 2008). Through the television medium, farmers can watch demonstration activities and gather a clear explanation of the content that is being presented by the extension agent. This is in line with the RTM customer charter that aims at ensuring each programme produced by RTM has high quality such as valid information and educational programmes that can inculcate positive attitudes and noble values (Syed et al., 2018).

The development of broadcasting facilities includes the launch of Malaysia's own satellites and broadcasting towers to meet the government's goal of accelerating communities' physical and intellectual development agenda throughout the country, including those in remote areas. The improving socio-economic development in the 1980s resulted in television having more significant potential to reach urban and rural communities easily both in development, training, resource planning, expansion, experience, and giving awareness (Akter \& Mezbah-ul-Islam, 2016 ). Therefore, all intensive planning for the expansion and implementation of television programmes should be considered by government and private agencies. However, the authorities have taken limited practical initiatives and research to develop television programme content for rural communities. Several previous studies found that it is more concentrated in urban areas than in rural areas, especially on effective television programmes for rural development.

In addition, television channels have shaped the socio-cultural pattern of society globally and consider television an important part of daily life. If before, there is no electronic device was capable of penetrating homes simultaneously to convey the same message to an audience comprised of age, illiteracy, and literacy as well as the rich and poor. Nowadays, the dissemination and delivery of information through television is becoming more widespread not only in urban communities but also among rural communities. This is also supported with the availabilty of sophisticated equipment such as satellites that are able to convey information along with images to the rest of the world at the same time.

According to Samani et al (2011) mass media is a necessity that is a medium to obtain various information such as education and health issues, government policies and policies, sports and entertainment for all levels of society. Therefore, the role of mass media such as television is important in conveying beneficial news to the community, especially when the information that is directly conveyed is highly trusted by the community. Not surprisingly, nowadays, most government prefers to use news broadcasting as a channel to disseminate information and announcements to the public, especially in Malaysia.

\section{Problem Statement}


The life of society today is influenced by the role of communication channels such as print media, electronic media and new media as a reference in daily life and determine the level of their quality of life. The acceptance of using television channels as media and essential tools in life is important to obtain information related to government policies, education and health issues, local and international sports, and entertainment. Sophistication in the display of communication channels has brought many advantages in life, in parallel with the rapidity of science and technology helps to improve the living standards of society. Nevertheless, exposure to this unlimited communication information invites various messages and information that require the recipient's discretion. This is because not all messages can be well received and meet their goal due to different interpretations by each recipient (Samani et al., 2011).

A part of complement for the transformation of rural development is to provide communication channels, including television channels, to convey information. However, the question often raised related to the level of effectiveness in using television channels in rural communities. The use of television channels is seen as less exciting or the information conveyed is challenging to be understood by the rural community due to educational constraints. Most rural communities have more trust and receive information through interpersonal communication than other communication channels that only serve as a facility for communication and entertainment alone. As a result, rural communities will not access any up-to-date information about government policies or any initiatives to improve their quality of life.

According to Bala et al (2000); Mansur et al (2013) rural communities typically use face-to-face communication to obtain information either through visitors who travel to their area or by their community itself. Farmers often use information sources through interpersonal communication from print and electronic media because these sources are more reliable and valid (Alan, 2009).

Most of the rural communities are actively involved with agricultural activities. Thus, agricultural information received from various sources by the rural communities will contribute to the needs and requirements of these communities in changing their quality of life in the future. Therefore, the research question is, what is the frequency by which Sarawak's rural communities use television to search for information? Meanwhile, this study aims to identify the frequency of television use among Sarawak's rural communities in the search for information.

\section{Diffusion of Innovation Theory}

Diffusion of Innovation Theory describes how a new idea and technology is to be introduced and disseminated in a community and society's culture. This theory was introduced by Everett M. Rogers in 1964 with the writing of a book entitled 'Diffusion of Innovations'. Based on this theory, a person who obtains information will turn that information into a guide and practice in their daily lives. The process of dissemination of information and new discoveries through the process of communication through certain channels and periods in accordance with the social system that exists in a community (Rogers, 2004).

The Diffusion Theory or Diffusion of Innovation explains the spread or application is a process in which an innovation is delivered through certain channels over time among members in a social system. The message conveyed is through the process of communication, in which the message emphasizes new ideas (Rogers, 1995; Fatonah \& Afifi, 2008). This theory explains the role of mass media including newspapers, radio and television. The role of the 
mass media emphasizes awareness after personal contexts and meetings between experts as well as advisory services are conducted. Ultimately experience drives the absorption of new technologies by the recipient of the information (Wok et al., 2006).

The diffusion of innovation is a process that transfers innovation through a channel to individuals in a social system over a period of time. This means that the process of diffusion of innovation has four main elements, namely: (1) the innovation itself, (2) the channels used to deliver it, (3) the members of the social system who receive the innovation and (4) the time taken. An innovation in a social living system when there is a new idea that can be put into practice through the practices performed by members in the community (Roger, 2003; Lee et al., 2011; Ntemana \& Olatukun, 2012).

The characteristics of an innovation determine the rate of acceptance. The five features of new technologies that have identified their acceptance (Rogers, 1995; Wok et al., 2006) are: (1) relative advantages (new technologies that more advance compared to existing technologies. For example, cheaper, easier to use and lighter), (2) compatibility (continuous rate with social implementation and norms among consumers), (3) complexity (easy to use and learn), (4) trialability (chance to try out the innovation before being fully utilized) and (5) obervability (the extent to which the technology clearly shows it benefits). These five factors determine the level of acceptance of an innovation that is diffused in the rural community. Innovations disseminated through communication methods to rural communities are usually aimed at improving daily living standards, whether in agriculture, health, nutrition, household economy, education and employment. Public acceptance of innovation will not happen simultaneously or directly. There are people ready to wait for the arrival of innovation because they are aware of the needs. There are also a category of people that will observe the innovation before adopting it. Another category of people, are those that will accept the innovation after being entirely convinced of the benefits to be obtained, while a category of people are those that do not want to accept the innovation (Rogers et al., 1971; Adnan \& Nasution, 1992).

\section{Methodology}

This study was conducted in Asap Koyan Resettlement in Belaga, Sarawak. The sampling method of the study is to use random sampling method. A structured questionnaire form was used in this study because this approach is more systematic and practical. This study uses a survey method with face-to-face interviews with respondents at locations chosen by respondents in accordance with their current situation. The survey method is an appropriate technique to use that involves a large population because this process is more direct in describing the actual situation of a population (Babbie, 2007). The use of this method is to reduce the unfairness of the results of the study.

Based on the statistically proposed sample size of 356 respondents, then random sampling was conducted to obtain respondents. Figure 1 shows the sampling framework of the study conducted in the study area. 


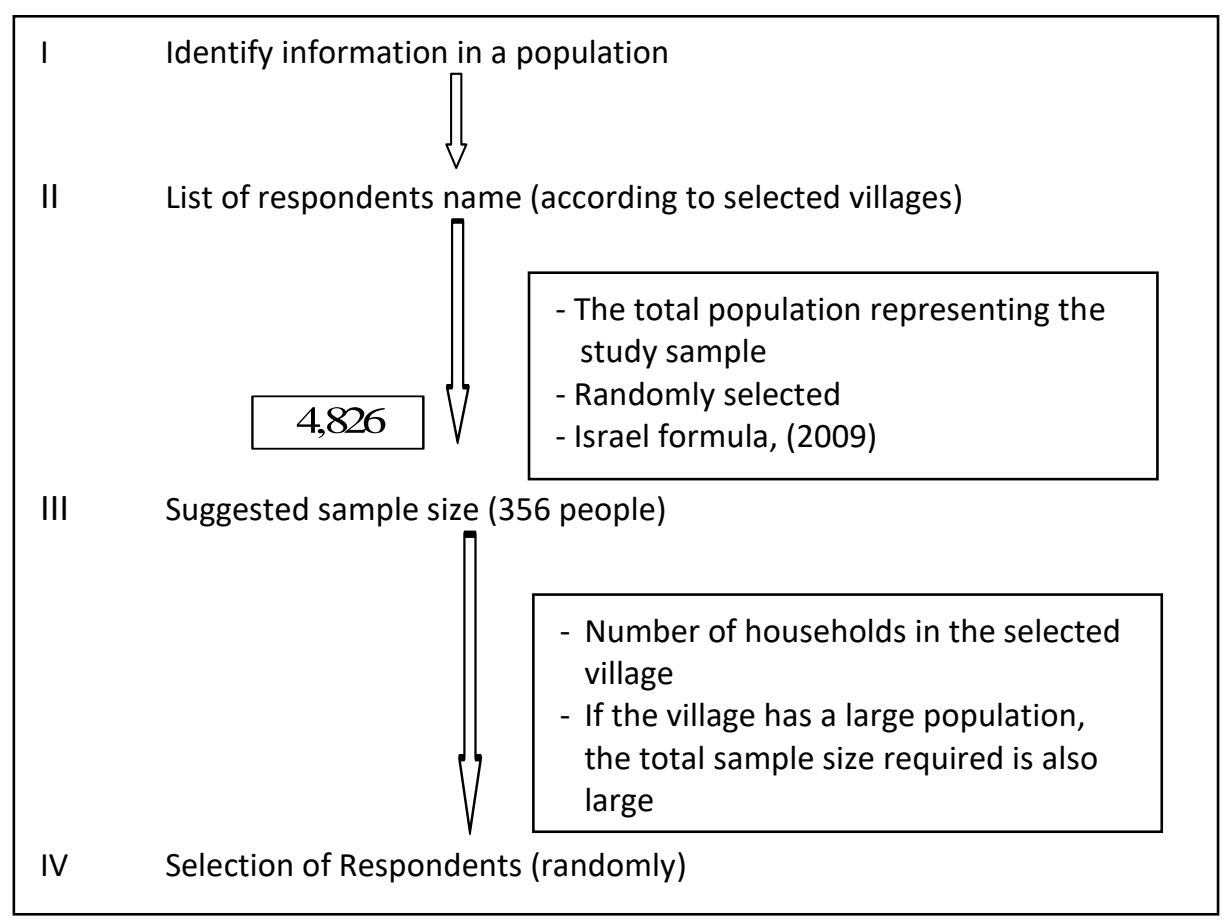

Figure1: Study framework sampling

The operation and measurement of variables for television channels include RTM, Media Prima, ASTRO (Irfan et al., 2006; Hassan et al., 2008; Hamzah \& Shaffril, 2009; Shaffril et al., 2009). Next, the nominal level is used to measure the operationalization of time, place, information and time averages. The ratio level is used to measure the frequency of watching television in a week. The measurement for the fifth question related to the frequency of watching television was 1 = never, 2 = rarely (once a week), 3 = sometimes (1-3 days/week, 4 = always (4-6 days/week), 5 = every Measurements for the fifth television question were $1=$ never, 2 = rarely (once a week), 3 = sometimes (1-3 days/ week), 4 = always (4-6 days/ week), $5=$ every. Based on this operation, television-related information is measured with items as in Table 1.

Table 1: Television variables

\begin{tabular}{ll}
\hline Variable & Item \\
\hline Television & 1. The main time of watching \\
& 2. The main place of watching \\
3. The time ratio of watching \\
4. The main information seeking \\
5. Frequency of watching within a week
\end{tabular}

\section{Result and Discussion}

\section{Profile of respondent}

The results of this study successfully interviewed 356 respondents using the survey method with face-to-face interviews. Table 2 shows the demographic of the respondents who participate in this study. More than half of the respondents were male $(56.7 \%)$ and only $43.3 \%$ were female. The majority of the respondents were adult youth aged 41 to 55 years old with a $51.7 \%$. The total percentage of the respondents in the range below 40 years old is $28.6 \%$, 
and they were categorized as junior youth. The findings and explanations obtain through faceto-face interviews indicate that young people in the study area are more likely to stay and migrate to the city to work in the public and private sectors. The remaining $13.2 \%$ of the respondents were in the age group of 56 to 70 years and those aged over 70 years were only $6.5 \%$.

The majority of respondents had the highest level of education at Primary school, which is $29.5 \%$. This finding is followed by Lower Certificate of Education (SRP) at $26.1 \%$, and Malaysian Education Certificate (SPM) or Malaysian Vocational Certificate of Education (SPMV) at $26.8 \%$. Further, $10.1 \%$ of respondents did not have any formal education, $3.9 \%$ of respondents have a bachelor or Master degree, and 2.5\% have a Malaysian Higher Certificate of Education (STPM) or Matriculation Programme or Certificate. At the same time, the remaining $2 \%$ were at the Diploma level (Table 2 ). These findings indicate that most of the respondents involved in this study have a low level of education especially among the farmers. Evidence of this low level of education supports that rural people with high levels of education are no longer inhabiting rural areas. This is because most junior youth are persistent to migrated and working in the city, parallel with their strong desires of seeking comfortable and better quality of living including employment, education, technology and leisure.

Table 2: Profile of respondents $(n=356)$

\begin{tabular}{ll}
\hline Profile & Precentage \\
\hline Gender & \\
Male & 56.7 \\
Female & 43.3 \\
Age & \\
$<25$ year & 0.8 \\
$26-40$ year & 27.8 \\
$41-55$ year & 51.7 \\
$56-70$ year & 13.2 \\
>70 year & 6.5 \\
Level of education & \\
Has no formal education & 10.1 \\
Primary school & 29.5 \\
SRP/PMR/PT3 & 26.1 \\
SPM/SPMV & 25.8 \\
STPM/Matriculation/Certificate & 2.5 \\
Diploma & 2.0 \\
Bachelor/Master & 3.9 \\
\hline \multicolumn{1}{l}{ Sources (Field Data, 2012) } & \\
\end{tabular}

\section{Descriptive Analysis}

Based on the findings, most of the rural communities in Sarawak are getting better, including the community in this study area with the availability of television channels in almost every household. Table 3 shows the time categories spent by the rural community to watch television channels. Since most of the respondents in this study are farmers, they spend most of their time working in the garden or farm during the daytime. Therefore, the result shows that rural community spends less time watching television in the morning. Most of the respondents were spend their time watching television during the evening and night because 
this is the relaxation time for them. In the evening, the highest television channel watched by respondents was Media Prima at $42.7 \%$ and followed by RTM at 39.6\%. However, most respondents watched the Astro channel (58.6\%) compared to other channels during the nighttime. The other channels stated in this study are the channel from Malaysia's neighboring countries, Indonesia and are known as Parabola.

Table 3: The frequent time of watching television

\begin{tabular}{llllll}
\hline & \multicolumn{2}{l}{ Frequency (\%) } & & \\
\cline { 2 - 5 } Television Channel & Mode & $\begin{array}{l}\text { Early } \\
\text { morning }\end{array}$ & Noon & Evening & Night \\
& & & & & \\
\hline RTM (TV1, TV2) & 3 & 24 & 72 & 141 & 89 \\
& & $(7.4)$ & $(22.1)$ & $(39.6)$ & $(27.3)$ \\
Media Prima (TV3) & 3 & 23 & 73 & 138 & 89 \\
& & $(7.1)$ & $(22.6)$ & $(42.7)$ & $(27.6)$ \\
ASTRO & 4 & 14 & 10 & 53 & 109 \\
& & $(7.5)$ & $(5.4)$ & $(28.5)$ & $(58.6)$ \\
Other & 4 & 14 & 16 & 60 & 116 \\
& & $(6.9)$ & $(7.9)$ & $(29.6)$ & $(56.3)$ \\
\hline
\end{tabular}

Note: 1=Early morning; 2=Noon; 3=Evening; 4=Night

Table 4 shows that most respondents allocate their time ranging from 30 to 59 minutes and more than 2 hours to watch a programme aired by the television channel. The programme aired by RTM ( $41.5 \%)$ has the highest percentage and followed by Media Prima $39.6 \%$, ranging from 30 to 59 minutes. For the time spends more than 2 hours, most respondents prefer to watch programmes aired by the Astro television channel $(62.7 \%)$ and others (55.3\%). This study reveals that most respondents spend more than 2 hours watching television programmes such as sports and movies, especially during nighttime, because that is the only time available to watch their favourite programmes and relax their minds. Interestingly, the findings of this study are not consistent with Murphy (2008), where Malaysians spend 1 hour 25 minutes reading newspapers and other print media in a day, 1 hour 33 minutes listening to the radio in a day, 1 hour 50 minutes to watching television, VCDs, DVDs and other video materials in a day.

This study shows that respondents of rural areas spend more time watching ASTRO and others (more than 2 hours) than television channel ( 1 hour 50 minutes). Since this study was on respondents of rural areas, the newspapers or other printing media were from a surrounding town. However, most of respondents are farmers and mostly spending their daytime at their farms. As a result, they only go to town whenever is necessary. Based on the finding of this study, ICT infrastructure for accessing the internet remains lower. Due to this matter, respondents have many difficulties to accessing other digital materials besides radio and television. Therefore, television was considered their primary source for respondents to gain the latest news, entertainment, knowledge, and leisure activities. The results indicating the importance roles of television for the rural areas community in Sarawak. 
Table 4: The time duration of watching television

\begin{tabular}{lllllll}
\hline \multirow{2}{*}{$\begin{array}{l}\text { Television } \\
\text { Channel }\end{array}$} & Mode & $<\mathbf{5}$ min & $\mathbf{5 - 2 9}$ min & $\mathbf{3 0 - 5 9}$ min & $\mathbf{6 0 - 1 1 9}$ min & hours \\
\hline RTM (TV1, TV2) & 3 & 17 & 119 & 134 & 34 & 19 \\
& & $(5.3)$ & $(36.8)$ & $(41.5)$ & $(10.5)$ & $(5.3)$ \\
Media Prima (TV3) & 3 & 19 & 118 & 127 & 36 & 21 \\
& & $(5.9)$ & $(36.8)$ & $(39.6)$ & $(11.2)$ & $(6.5)$ \\
ASTRO & 5 & 1 & 11 & 23 & 35 & 116 \\
& & $(0.3)$ & $(5.9)$ & $(12.4)$ & $(18.9)$ & $(62.7)$ \\
Other & 5 & 2 & 16 & 42 & 32 & 114 \\
& & $(1.0)$ & $(7.8)$ & $(20.4)$ & $(15.5)$ & $(55.3)$ \\
\hline
\end{tabular}
hours

Table 5 reveals that almost all respondents prefer longhouses as the main place to watch television programmes aired by others (84.8\%), RTM (81.1\%), Media Prima (78.8\%) and Astro (73.1\%). The respondents can watch programmes aired by RTM and Astro in all places listed except while gardening. It is also noted that respondents can still watch programmes aired by Media Prima (0.9\%) and others $(0.5 \%)$ while gardening. Based on the mode, more respondents are in the longhouse at night to watch television, which is only available at home.

Table 5: The location of watching television

\begin{tabular}{|c|c|c|c|c|c|c|}
\hline \multirow[b]{2}{*}{ Television Channel } & \multirow[b]{2}{*}{ Mode } & \multicolumn{2}{|c|}{ Frequency (\%) } & \multirow[b]{2}{*}{ Town } & \multirow[b]{2}{*}{ City } & \multirow[b]{2}{*}{ Other } \\
\hline & & Longhouse & $\begin{array}{l}\text { While } \\
\text { gardening }\end{array}$ & & & \\
\hline RTM (TV1, TV2) & 1 & $\begin{array}{l}262 \\
(81.1)\end{array}$ & & $\begin{array}{l}9 \\
(2.8)\end{array}$ & $\begin{array}{l}37 \\
(11.5)\end{array}$ & $\begin{array}{l}15 \\
(4.6)\end{array}$ \\
\hline Media Prima (TV3) & 1 & $\begin{array}{l}253 \\
(78.8)\end{array}$ & $\begin{array}{l}3 \\
(0.9)\end{array}$ & $\begin{array}{l}12 \\
(3.7)\end{array}$ & $\begin{array}{l}35 \\
(10.9)\end{array}$ & $\begin{array}{l}18 \\
(5.6)\end{array}$ \\
\hline ASTRO & 1 & $\begin{array}{l}136 \\
(73.1)\end{array}$ & & $\begin{array}{l}12 \\
(6.5)\end{array}$ & $\begin{array}{l}32 \\
(17.2)\end{array}$ & $\begin{array}{l}6 \\
(3.2)\end{array}$ \\
\hline Other & 1 & $\begin{array}{l}173 \\
(84.8)\end{array}$ & $\begin{array}{l}1 \\
(0.5)\end{array}$ & $\begin{array}{l}5 \\
(2.4)\end{array}$ & $\begin{array}{l}6 \\
(1.7)\end{array}$ & $\begin{array}{l}21 \\
(10.2)\end{array}$ \\
\hline
\end{tabular}

Note: 1=Long House; $2=$ While gardening; $3=$ Town; $4=$ City; $5=$ Other place

According to Ifukor (2013), television is one of the channels used to disseminate information among the rural population. Therefore, it is suggested that indigenous languages should be used for television news. This could enable the rural community to better understand in the message conveyed. Mtega (2012) stated that the rural population accesses information mainly through radio, television, newspapers, and information sources, depending mainly on the level of education, income of the rural community, gender, age, and occupation. Therefore, it is recommended for the information needs of rural communities periodic assessment and re-updating of information in an appropriate form to meet the needs of people, especially in rural areas.

Table 6 shows that the main information sought by respondents through television channels is government information through Media Prima (44.2\%) and RTM (39.2\%). As for 
the Astro channel, the main information sought was more related to sports and recreation, which was $43.9 \%$. Further, $47.6 \%$ of respondents watch other channels to obtain other information. Respondents watch television through RTM and Media Prima channels mainly to focus on knowledge related to government information, especially current developments in the country and abroad. The respondents mainly watch the ASTRO channel for sports and recreation information. They also watch other broadcasts to seek other information related to entertainment, religion and other culture outside of Malaysia. The other broadcasts are watched by respondents because such programmes are less broadcast by RTM and Media Prima. Therefore, these findings are not in line with a study conducted by Hassan et al. (2008) where farmers watch television to obtain information about weather, agricultural markets and information related to ICT. According to Adenkule et al (2002) the farmers' communities aged between 35 years and below have the ownership of more televisions and obtain more agricultural information from television. This is contradictory to these findings because the respondents aged 35 and above prefer to watch religious and economic programmes rather than programmes with agriculture content.

Table 7 shows the frequency of the respondents watching television within a week. The findings show that most respondents have never and rarely watched television within a week and $47.8 \%$ of respondents have never watched television through the Astro channel. Interestingly, $42.1 \%$ of the respondents have never watched other channels because they do not have the facilities of that television channel. Apart from that, respondents also stated that they rarely watched programmes aired by RTM (39.6\%) and Media Prima (37.4\%). These findings are very closely related to the career and age of the respondents, who are mostly more concerned with their energy rejuvination in order to stay fit for work, which contributes to the activity of the frequency of watching television. 
INTERNATIONAL JOURNAL OF ACADEMIC RESEARCH IN BUSINESS AND SOCIAL SCIENCES Vol. 11, No. 11, 2021, E-ISSN: 2222-6990 @ 2021 HRMARS

Table 6: The main information seeking from television

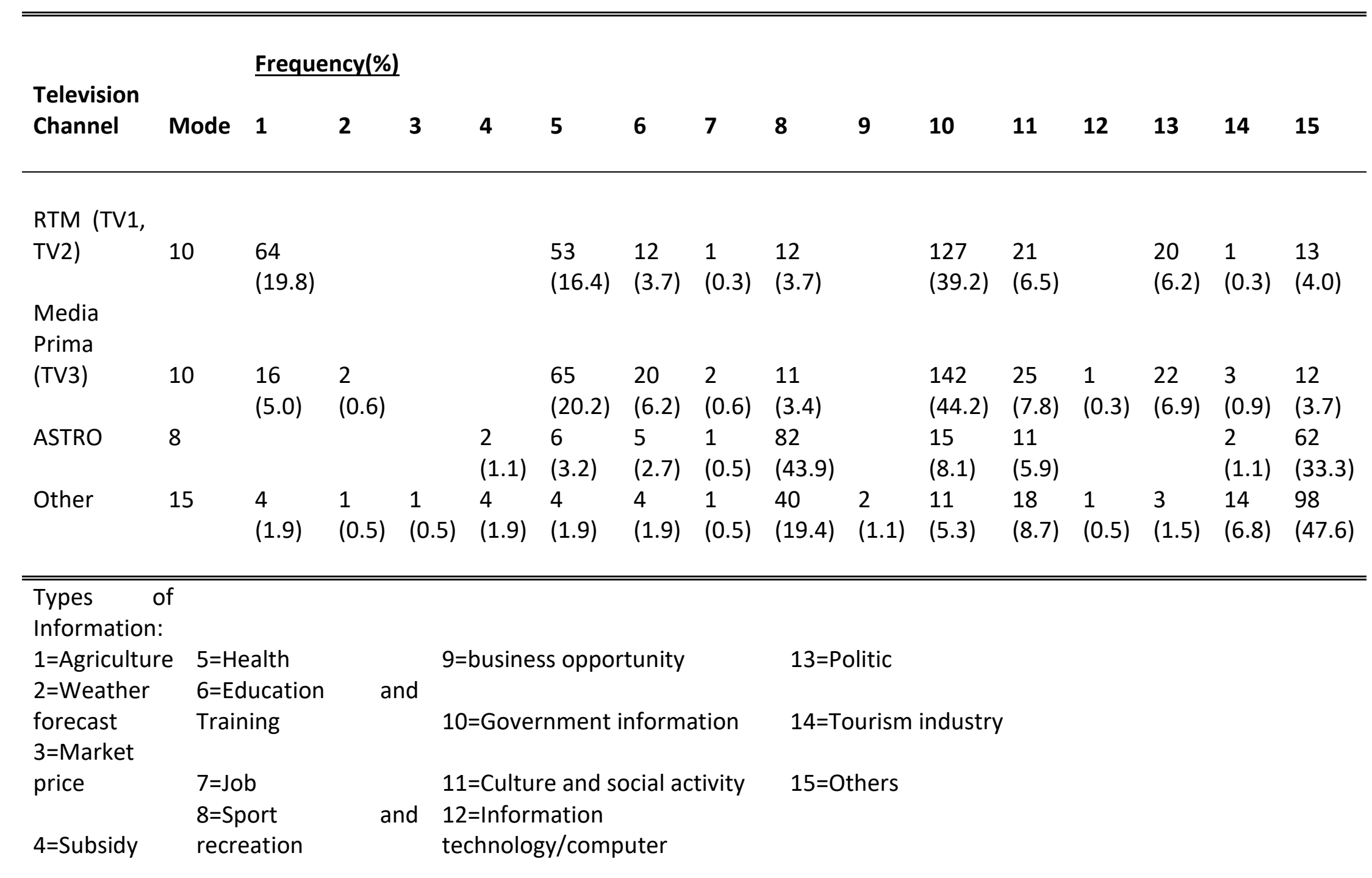


Table 7: Frequency of watching television within a week

\begin{tabular}{llllllll}
\hline \multirow{2}{*}{ Television Channel } & & \multicolumn{2}{l}{ Frequency (\%) } & & \\
\cline { 4 - 7 } & & Mode & Never & Rarely & Sometimes & Often & Always \\
& & & & & & & \\
\hline RTM (TV1, TV2) & 2 & 33 & 141 & 54 & 48 & 80 \\
& & $(9.3)$ & $(39.6)$ & $(15.2)$ & $(13.5)$ & $(22.5)$ \\
Media Prima (TV3) & 2 & 37 & 133 & 54 & 45 & 87 \\
& & $(10.4)$ & $(37.4)$ & $(15.2)$ & $(12.6)$ & $(24.4)$ \\
ASTRO & 1 & 170 & 68 & 9 & 27 & 82 \\
& & $(47.8)$ & $(19.1)$ & $(2.5)$ & $(7.6)$ & $(23.0)$ \\
Others & 1 & 150 & 93 & 74 & 17 & 22 \\
& & $(42.1)$ & $(26.1)$ & $(20.8)$ & $(4.8)$ & $(6.2)$ \\
\hline
\end{tabular}

Note: $1=$ Never; $2=$ Rarely; $3=$ Sometimes; $4=$ Often; $5=$ Always

Based on the selection of television channels watched daily by the respondents, the respondents prefer to choose Media Prima (24.4\%), Astro (23.0\%), RTM 22.5\%, and followed by others (6.2\%). Based on the percentage of watching these television channels, it is more related to the ability to own and subscribes to the television channels among the respondents. This study exposes that most respondents are not able to watch television over prolonged time periods because sometimes spent their nighttime at their farms that are located far away from their longhouse. Besides that, respondents tends not to watch television due to physical fatigue, that is the tiredness after whole day working at the farm. Besides that, some of the respondents were observed to be more likely to watch television on weekends because on working days, they are more likely to rest and they can save money. Lately, the increment in the percentage of television channels as one of the methods of obtaining information and entertainment is due to the large ownership and installation of digital multimedia terminals in rural areas pioneered by ASTRO. This helps the remote areas to access the television channels.

Television stations also presenting entertainment programmes and agriculturalrelated information that attract the audience, but the broadcast times are inappropriate and not relevant to the audience's needs. According to Ramli et al (2013) the programme presented will be useless if the target audience cannot view the information. Studies obtained by Ali et al (2010); Hassan et al (2011) also found that audience ratings significantly increased when the programme was broadcast in prime time. Nazari and Hassan (2011) claimed that the issue of inappropriate broadcast time is always raised as a major problem faced by farmers.

The results of this study are not consistent with the Diffusion Theory of Innovation (Roger, 1995), stating that television is one of the mass media that can influence the audience to accept the changes because of the element of persuasion and it has advantages in conveying information to recipients through involvement in social, cultural activities and entertainment. This may be due to the increasing use of mobile phones among rural communities who prefer to choose this devices to connect with internet line for seek information. According to Roger (1995), interpersonal communication is an effective channel because it can influence society to accept the changes because of the element of persuasion. In addition, rural communities should be adopting new technologies and use new ideas in their farms and homes through effective communication methods in addition to other mass media (Roger, 2003). 


\section{Conclusion}

Television in the community in rural villages of Sarawak is still very relevant to the purpose of socio-economic development as a whole. However, the use of television based on the findings of this study is seen as just a need in the house to be used at a certain time because the respondents consist of adult youth at the age of 41-55 years, they show less television viewing among them. Similarly, television channels for most respondents have a primary school level of education in this study which is $29.5 \%$, which is a sign that they are less interested in watching television. In terms of the pattern of watching respondents through television channels, divided into two groups, some prefer to choose the evening to watch TV1, TV2 and TV3, while the night to watch ASTRO and other channels with a time of 30 to 59 minutes allocated to watch RTM and Media Prima channels and Astro channels and the allotted time is more than 2 hours. The main place to watch their favourite shows is in the longhouse by using television to get government information, sports and recreation and others. Overall, residents clearly watch television depending on their household's economic ability to own the type of broadcast.

In-depth studies need to be continued to identify the factors that influence television channel viewing in particular to seek information. This is because the use of television channels has great potential in shaping the development of the country in the future. The roles of television channels to rural communities have a significant impact on the income of rural communities involved in the study based on significant changes in 20 years from never using television channels to seek information or own a television to own a television. Similarly, the improvement of the level of infrastructure for the needs of the television coverage system provides an opportunity for the rural community to get good coverage.

In conclusion, the changes in television viewing of the rural community in Sarawak involved in the study are seen to play a role in the development of agriculture which is more inclined to increase their income and level of education. The use of television channels as a source of knowledge in agriculture among rural communities is still low. Limited ownership and poor infrastructure supporting its use are some of the factors that limit the level of use of this channel. Therefore, it is recommended that television stations promote their agricultural programs before airing them every week for the benefit of rural farmers. The government should also reduce tariffs and taxes related to television ownership to encourage them to continue using these channels to obtain information.

\section{Acknowledgment}

This research project is sponsored by the Ministry of Education Malaysia. Thank you to all respondents who are involved in this research.

\section{References}

Adenkule, A. A., Onyibe, J. E., Ogunyinka, O. M., Omenesa, Z. E., Auta, S. J., \& Kuyello, A. U. (2002). Agricultural information dissemination: An audience in Kano State. International Institute of Tropical Agriculture (IITA): Nigeria.

Adnan, M. H., \& Nasution, Z. (1992). Komunikasi pembangunan: Pengenalan dan penerapan. Kuala Lumpur: Dewan Bahasa dan Pustaka.

Akter, R., \& Mezbah-ul-Islam, M. (2016). Television as a Medium of Information for Rural Development in Bangladesh: A Case Study of Dinajpur District. Conference: 10th Convention PLANNER. 
Alan, R., Hassan, M. S., Hassan, M. A., \& Lepun, P. (2009). Tahap keperluan maklumat dan kredibiliti sumber maklumat teknologi pertanian dalam kalangan pekebun kecil ada hitam di kawasan luar bandar. Dalam Samah, B.A., Uli, J., and Alavi, K. (eds.) Media dan Pengembangan Pertanian: ke Arah Memperkasakan Komuniti Luar Bandar, pp. 121137. Serdang: Penerbit Universiti Putra Malaysia.

Ali, M. S. S., Hassan, M. S., Samah, B. A., \& Shaffril, H. A. M. (2010). Decision making in producing agricultural television programmes in Malaysia. Paper accepted for presentation at International Conference: Future Imperatives of Communication and Information for Development and Social Change, Bangkok. December 20-22, 2010. Retrieved from http://www.jcconference. co.cc/.it.

Babbie, E. (2007). The practice of social research. (11 $1^{\text {th }}$ Ed.). Belmont: Wadsworth.

Bala, P., Khoo, E., Songan, P., \& Harris, R. W. (2000). Potential users profile and existing communication pattern among the rural community of Bario: A needs analysis for the development of a telecentre. In Leigh, M. (Ed.), Borneo 2000: Politics, history \& development (pp. 626-647). Kota Samarahan, Sarawak, Malaysia: Universiti Malaysia Sarawak.

Fatonah, S., \& Afifi, S. (2008). Difusi teknologi tepat guna di kalangan wanita pengusaha di desa Kasongan Yogyakarta. Jurnal IImu Komunikasi, 6(1), 41-45. https://doi.org/10.31315/jik.v6i1.39

Hamzah, A., \& Shaffril, H. A. M. (2009). Sejarah, prinsip dan keperluan pengembangan pertanian. Dalam Bahaman Abu Samah, Jegak Uli dan Khadijah Alavi (Eds.). Media pengembangan pertanian ke arah memperkasakan komuniti luar bandar. Serdang: Penerbit Universiti Putra Malaysia.

Hassan, M. S., Yassin, S. M., Shaffril, H. A. M., Othman, M. S., Samah, B. A., Samah, A. A., \& Ramli, S. A. (2011). Receiving the agriculture information through mass media and interpersonal sources among the rural community. American Journal of Agricultural and Biological Sciences, 6(3), 451-461.

Hassan, M. S., Hassan, M. A., Samah, B. A.., Ismail, N., \& Shaffril, H. A. M. (2008). Use of internet among agri-based entrepreneurs in Peninsular Malaysia. Kertas Kerja dibentangkan di International Conference Cum SEARCA Alumni Homecoming. Los Banos, Filipina.

Hashim, H., \& Omar, B. (2011). Transformasi penyiaran televisyen melalui internet: kajian perhubungan kepuasan terhadap pengguna remaja. Jurnal Komunikasi, 27(1), 146-169.

Ifukor, M. O. (2013). Channels of information acquisition and dissemination among rural dwellers. International Journal of Library and Information Science, 5(10), 306-312. DOI: 10.5897/IJLIS11.036

Irfan, M., Muhammad, S., Khan, A., \& Asif, M. (2006). Role od mass media in the dissemination of agricultural technologies among farmers. International Journal of Agriculture and Biology, 8(3), 417-419.

Lee, Y. H., Hsieh, Y. C., \& Hsu, C. N. (2011). Adding Innovation Diffusion Theory to the Technology Acceptance Model: supporting employees' intentions to use E-Learning Systems. Educational Technology and Society, 14(4), 124-137.

Mansur, N., Zakaria, Z., \& Daud, C. H. R. (2013). Quality of life in the 21th century: narrowing the gap between rural and urban area. International Journal of Business and Social Science, 4(5), 186-195.

Syed, M. A., \& Ibrahim, M. N. (2018). Literasi media, cabaran penyiaran sosial dan kelangsungan industri televisyen di Malaysia. Forum Malaysia, 13(1), 15-40. 
Mtega, W. P. (2012). Access to and usage of information among rural communities: a case study of Kilosa district Morogoro region in Tanzania. The Canadian Journal of Liebrary and Information Practice and Research, 7(1), 1-13.

Murphy, S. (2008). Insights into critical trends that are shaping the lives of Malaysian consumers. Retrieved from http://www.adoimagazines.com/ newhome/images/docs/5\%20hot\%20trends\%20\%for\%Malaysia.pdf.

Nazari, M. R., \& Hassan, M. S. (2011). The role of television in the enhancement of farmers' agricultural knowledge. African Journal of Agriculture Research, 6(4), 931-936. doi: 10.5897/AJAR10.1154

Ntemana, T. J., \& Olatukun, W. (2012). Analyzing the influence of diffusion of innovation attributes on lecturers' attitudes toward information and communication technologies. Journal on Human in ICT Environments, 8(2), 179-197.

doi:10.17011/ht/urn.201211203034

Ramli, N. S., Hassan, M. S., Samah, B, A., \& Ali, M. S. S. (2013). Problems in using agricultural information from television among farmers in Malaysia, Asian Social Science, 9(9), 7073. doi:10.5539/ass.v9n9p70

Rogers, E. M., \& Shoemaker, F. F. (1971). Communication of innovations: A cross- cultural approach. ( $2^{\text {nd }}$ Ed.). New York: The Free Press.

Rogers, E. M. (1995). Diffussion of innovations (4 ${ }^{\text {th }}$ Ed.). New York: The Free Press.

Roger,E. M. (2003). Diffussion of innovations (5 ${ }^{\text {th }}$ Ed.). New York: The Free Press.

Rogers, E. M. (2004). Diffusion of innovations ( $5^{\text {th }}$ Ed.). New York: Free Press.

Shaffril, H. A. M., Hassan, M. S., \& Samah, B. A. (2009). Level of agro-based website surfing among Malaysian Agricultural Entreprenuers: A case of Malaysia. Journal of Agriculture Extension and Social Science, 5(3), 55-60.

Samani, M. C., Maliki, J., \& Rashid, N. A. (2011). Literasi media: ke arah melahirkan pengguna media berpengetahuan. Jurnal Pengajian Media Malaysia, 13(20), 41-64.

Wawarah, S. (2017). Televisyen medium dakwah: Peranan, pengaruh dan cabaran. 4th International Research Management \& Innovation Conference (IRMIC 2017) Institut Latihan Malaysia (ILIM) Bangi, 7 September 2017.

Wok, S., Ismail, N., \& Hussain, M. Y. (2006). Teori-teori komunikasi. Kuala Lumpur: PTS Publications \& Distributors Sdn. Bhd. 